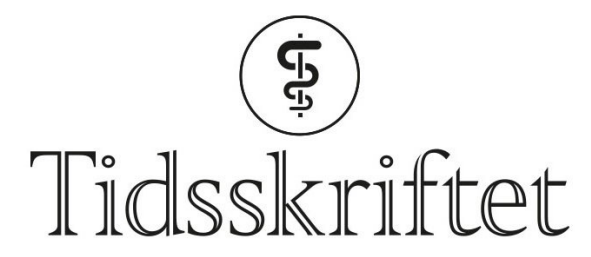

DEN NORSKE LEGEFORENING

\title{
Kreftrisiko ved tilfeldige radiologiske funn
}

FRA ANDRE TIDSSKRIFTER

KETIL SLAGSTAD

Tidsskriftet

Hyppigheten av tilfeldige radiologiske funn, og om de representerer kreftsykdom, varierer med bildemodalitet og kroppsdel som undersøkes. Det viser en ny studie.

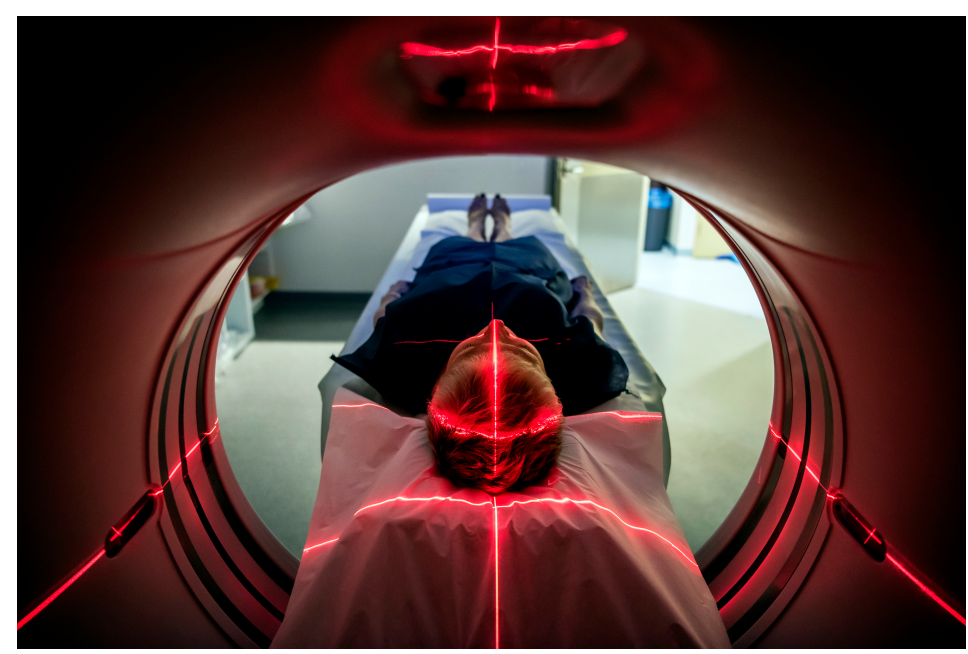

Illustrasjonsfoto:JohnnyGreig/iStock

Ved radiologiske undersøkelser påvises ikke sjelden tilfeldige funn. Hva betyr slike funn? En paraplyoversikt som nylig er publisert i tidsskriftet $B M J$ (1), omfattet 20 systematiske oversikter om dette temaet med 240 primærstudier med over 627 ooo pasienter. I paraplyoversikter gjøres det en oversikt over systematiske oversikter av høy metodisk kvalitet. Påfølgende metaanalyser viste at forekomsten av tilfeldige radiologiske funn varierte svært mellom ulike radiologiske undersøkelser. Forekomsten var høyest ved CT thorax for tilfeldige funn i thorax, abdomen, ryggrad og hjerte (45\%), CT-kolografi (38\%) og MR av hjertet (34\%). Forekomsten var lavest for funn av tilfeldige lungeembolier ved CT thorax (2\%). Tilfeldige funn som viste seg å være kreftsykdom, var vanligst i bryst (42\%) og eggstokker $(28 \%)$ og sjelden i hjerne, glandula parotis og binyrer $(<5 \%)$.

- Denne studien er basert på aggregerte data i et såkalt paraplydesign, etterfulgt av nye metaanalyser og kritisk vurdering av studienes kvalitet, sier Ingfrid S. Haldorsen, som er professor i radiologi ved Universitetet i Bergen. Funnene må antas å være overførbare til Norge, ettersom sykdomsprevalens, levealder og tilgjengelighet av aktuell bildediagnostikk hos oss er rimelig sammenlignbar med øvrige vestlige land. - Studien gir en god oversikt 
over forekomst av bifunn ved de ulike bildeundersøkelsesmetodene og i hvor stor grad disse viser seg å være kreft, sier Haldorsen.

LITTERATUR:

1. O'Sullivan JW, Muntinga T, Grigg S et al. Prevalence and outcomes of incidental imaging findings: umbrella review. BMJ 2018;361: k2387. [PubMed][CrossRef]

Publisert: 17. september 2018. Tidsskr Nor Legeforen. DOI: 10.4045/tidsskr.18.0533

(C) Tidsskrift for Den norske legeforening 2020. Lastet ned fra tidsskriftet.no 